\title{
有明海流入主要河川の流入負荷特性 INFLOW LOADS CHARACTERISTICS OF MAJOR RIVERS FLOWING INTO THE ARIAKE SEA
}

\author{
緒方直人 $1 \cdot$ 大串浩一郎 $2 \cdot$ 手塚公裕 3 \\ Naoto OGATA, Koichiro OHGUSHI and Masahiro TEZUKA \\ 1学生会員 佐賀大学大学院工学系研究科（７840-8502 佐賀市本庄町1番地） \\ 2正会員 博士（工学）佐賀大学大学院工学系研究科 教授 （广840-8502 佐賀市本庄町1番地） \\ 3正会員 博士（工学） 日本大学工学部土木工学科 助教 （ T963-8642 郡山市田村町徳定字中河原 1)
}

This study examines a relationship between rainfall, land use and inflow loads of major rivers flowing into the Ariake Sea. Inflow loads are estimated by normal or freshet stage of water discharge. A multiple regression analysis is implemented to obtain both factor for characterizing the inflow loads and those of varying the amount of the inflow loads. From 1976 to 2006, the change of land use were not dominant in the river basins for the Ariake Sea. The Rainfall patterns, change were not recognized in the Ariake sea basin from 1981 to 2010 . The river basin areas affect the inflow discharge and loads of COD, T-N and TP. The land use greatly affects the inflow loads.

Key Words : major rivers flowing into the Ariake Sea, inflow loads characteristics, long-term variation multiple regression analysis

\section{1. はじめに}

有明海では，1980年代に漁獲量の減少が始まり，2000 年12月に生じた大規模赤潮に伴うノリ不作をきっかけに 環境異変が注目された. 2002年には「有明海及び八代海 を再生するための特別措置に関する法律」が施行され, その後, 有明海における環境異変の原因解明と対策が進 められてきたが，明らかにされていない問題が未だに多 く存在している.

有明海の環境異変解明に関する検討として，堤ら ${ }^{1)}$ 小松ら ${ }^{2)}$ は有明海の赤潮発生のメカニズムや物質輸送の 変化に関する検討を行っている. しかし，東京湾や瀬戸 内海よりも閉鎖性が強いにも関わらず，有明海では陸域 の影響に関する知見は少なく，検討が必要となっている.

環境省有明海・八代海総合調査評価委員会の報告書 ${ }^{3)}$ では，1965 2001年の年流入負荷量の一部が算定されて いる. 朴ら ${ }^{4)}$ は, 有明海流入河川流域の分布型流出モデ ルを構築し, 土地利用等の環境変化が流出水量に与える 影響を考察している。しかし，これらの報告では幾つか の代表年を対象とした断続的な検討にとどまっており， 有明海流入河川ごとの検討も不十分である. 有明海の環 境変化のメカニズムを把握するためには，有明海に流入 する主要河川について連続的なデータを用いた流域特性 や土地利用の影響についての検討が必要である.また,
流入負荷が有明海の赤潮に影響することは明らかであり

5)，対策を検討するためにも，有明海流入主要河川の流 入特性を把握しておくことが望ましい，また，閉鎖性の 強い海域に流入する河川の特性を把握するため, 流入負 荷を平水時と出水時に分けて検討した研究のはあるが, 長期的な流入特性の検討はあまり見られない.

一方，流入負荷が海洋環境に及ぼす影響を定量的に把 握するためには，流域地形を詳細に考慮することが可能 な分布型流出モデルを構築することが有効であるといわ れている7). 分布型流出モデルを構築するためには，流 域の各構成要因（標高, 地質等）が流入負荷に及ぼす影 響や環境変動要因（降雨量，人口等）が流入負荷の変動 に及ぼす影響を定量的に把握することが望ましい。しか し，このような流域の各因子が流入負荷に与える影響に ついて検討を行っている研究は少ない.

そこで本研究では，著者らが既往の研究5) で推定した 1981 2010年（30年間）の主要河川の流入水量・負荷量 データを用いて，土地利用，降雨との関係性および平水 時と出水時における流入特性の河川毎の相違を検討した。 また，複数の流域構成要因の中で流入水量・負荷量に影 響を及ぼす因子を把握するため，まず有明海主要11河川 全てを対象とした重回帰分析を行った。 そして，影響が あると判断された流域構成要因と環境変動要因を用いた 重回帰分析により，各河川の流入水量・負荷量に及ぼす 因子と影響度を検討した。 


\section{2. 研究方法}

\section{（1）河川流域データの整理}

本研究では有明海流入主要河川（全一級河川および二 級河川であるが流域面積の大きい塩田川）の流域構造が 単純な順流域を対象に検討を行った(図-1).

有明海流入主要河川順流域からの流入水量・負荷量は 既往の研究5)より推定したデータを用いた。流入水量は, 順流域末端地点の時刻流量データの欠測を補間し, 1981 2010年のデータを推定した。負荷量は，順流域最 下流の観測所の水質データ(1981 2010年)を収集し、流 量と負荷量の関係式（L-Q式）から推定した.

主要河川流域の土地利用の変遷を見るため, 国土交通 省国土数值情報より入手した土地利用データ (1976,1987, 1991,1997,2006年)を田，畑，市街地，山林，その他（荒 地，水域等）に分類を統一し，GIS解析により土地利用 の割合を算出した.

主要河川順流域の降雨パターンの長期変化を検証する ため, 図-1に示す雨量観測所の1981 2010年における時 間雨量データを用いて，ティーセン法により流域平均雨 量を算定し, 降雨特性を把握するため, 年間降雨量, 豪 雨回数（時間雨量 $20 \mathrm{~mm}$ 以上），降雨時間数を算出した 本研究で用いた主要河川の流量・負荷量のデータは著 者らが既往の研究5)で推定した過去30年間(1981 2010年) のデータを用いた．また，流出機構の異なる平水時と出 水時に分類し，河川ごとの流出特性を把握した．平水時 と出水時の分類方法は既往の研究 ${ }^{5)}$ においてL-Q式を作 成した際の分類基準比流量を使用し，比流量が $0.1 \mathrm{~m}^{3}$. $\mathrm{km}^{-2} \cdot \mathrm{s}^{-1}$ 以下の時を平水時, それよりも大きい時を出水 時とした.

\section{（2）流入水量・流入負荷量に影響を及ぼす流域構成要因 の抽出方法}

流域構成要因が流入水量, 流入負荷量に及ぼす影響を 把握するため, 主要河川順流域全てを対象に重回帰分析 を行った. ここでは流域面積や土地利用割合の異なる11

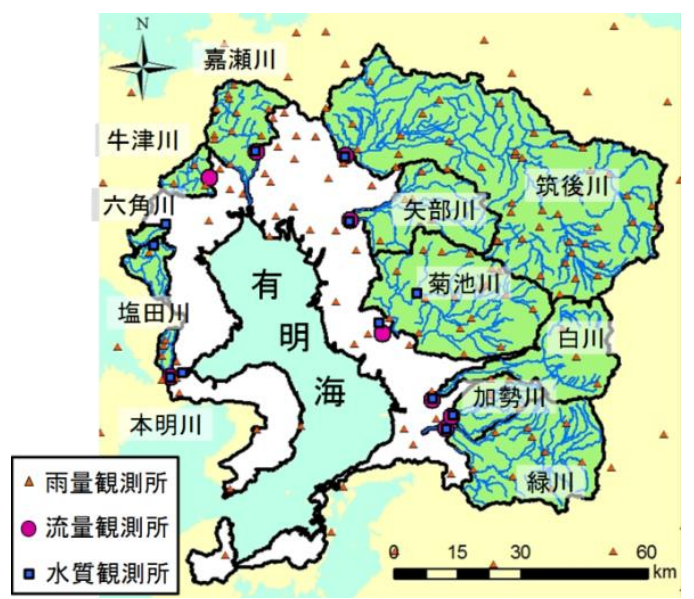

図-1＼cjkstart本研究における対象流域と各観測所
流域を合わせて解析することで，流域構成要素の影響を 明らかにした。

重回帰分析に用いた目的変数と説明変数を表-1に示寸. 目的変数は, 既往の研究で推定した流入水量とCOD, T-N，T-P負荷量とし，説明变数は土地利用割合（田， 畑，市街地，山林），平均傾斜角度，平均標高，流域面 積，地質指標，土壌指標，ダム湛水面積，流域人口，製 造品出荷額, 家畜数 (牛, 豚) とした.

土地利用割合，平均傾斜角度，平均標高，流域面積は， 国土数值情報の土地利用3次メッシュ $(1976,1987,1991$, 1997,2006年), 標高傾斜度3次メッシュデータのGIS解析 により算出した. ダム湛水面積は，ダム年鑑8)からダム 運用開始年とダム湛水面積を抽出し，1981 2010年にお ける各河川流域のダム湛水面積を算出した. 地質指標, 土袞指標は国土交通省土地分類基本調査から入手した表 層地質図(1968年)，土壌図(1968年)を用いてGIS解析によ り各地質と土㙵の種別面積を算出した．地質，土壌種別 ごとにダミ一変数を振り分け，それらに各種別面積を乗 じて合計したものを各河川流域の地質指標，土壌指標と した. なお，地質，土壤の経年変化は小さいと考える. 流域人口は総務省統計局から入手した都道府県別人口 (1981 2010年) とGIS解析で算出した都道府県別面積から 各都道府県の1981 2010年における人口密度を算出し， 対応した都道府県別に各流域面積を乗じることで各河川 の流域人口を算出した. 製造品出荷額, 家畜数は有明海 水域に係る下水道整備総合計画に関する基本方針策定調 查報告書（有明流総） $\left.{ }^{9}\right)$ の流域フレーム $(1995,2000$, 2005,2010年)を使用した。既往の研究)で推定した流入 水量・各負荷量や後述する土地利用等の連続データは経 年的な変化がないと考えられたため, 年平均值をとるこ とで各流域の代表值とした。

重回帰分析の説明変数の決定方法はステップワイズ法 を用い，重回帰分析の精度を決定係数 $\left(\mathrm{R}^{2}\right)$ と自由度調整 済多決定係数（補正済多 $\mathrm{R}^{2}$ ) で評価した。流入水量と各 負荷量に及ぼす影響度の指標として標準偏回帰係数を用 い，この值の絶対值が高いほど影響度が大きい。

多重共線性を回避するため各流域構成要因の合計を算

表-1 流域構成要因解析に用いて変数とその入手元

\begin{tabular}{|c|c|c|c|}
\hline 使用変数 & 項目 & 単位 & データの入手元 \\
\hline \multirow{4}{*}{ 目的変数 } & 流入水量 & $\mathrm{m}^{3} /$ year & \multirow{4}{*}{ 既往の研究 ${ }^{5)}$} \\
\hline & COD負荷量 & ton/year & \\
\hline & T-N負荷量 & ton/year & \\
\hline & T-P負荷量 & ton/year & \\
\hline \multirow{14}{*}{ 説明変数 } & 田割合 & $\%$ & \multirow{6}{*}{ 国土交通省 国土数値情報 } \\
\hline & 畑割合 & $\%$ & \\
\hline & 市街地割合 & $\%$ & \\
\hline & 山林割合 & $\%$ & \\
\hline & 平均標高 & $\mathrm{m}$ & \\
\hline & 平均傾斜角度 & 0 & \\
\hline & 流域面積 & $\mathrm{km}^{2}$ & GIS解析より算出 \\
\hline & 地質指標 & & \multirow{2}{*}{ 国土交通省 土地分類基本調査 } \\
\hline & 土壤指標 & & \\
\hline & ダム湛水面積 & ha & ダム年鑑 $(2011)^{8)}$ \\
\hline & 流域人口 & 人 & 総務省 統計局 \\
\hline & 製造品出荷額 & 万円 & \multirow{3}{*}{ 有明流総 ${ }^{9}$} \\
\hline & 牛 & 頭 & \\
\hline & 豚 & 頭 & \\
\hline
\end{tabular}


出し, 各流域構成要因を各合計值で除した值を説明変数 として用いた。また，説明変数間の多重共線性を表す VIF (Variance Inflation Factor : 分散拡大要因)の值が10以上 で問題とされている. 本研究で重回帰分析に用いた全て の説明変数でVIFを算出した結果，全説明変数でVIFが 10を下回り多重共線性がないことを確認した。

\section{（3）流入水量・負荷量に影響を及ぼす環境変動要因の抽 出方法}

各河川流域からの流入水量・負荷量の変動に影響を及 ぼす要因を把握するため，有明海流入主要11河川を河川 ごとに重回帰分析を行った. ここでは11流域を個別に解 析することで，各流域における影響因子を明らかにした

重回帰分析に用いた目的変数と説明変数を表-2に示寸. 目的変数は既往の研究 ${ }^{\text {( ) }}$ で推定した1981 2010年の流入 水量とCOD，T-N，T-P負荷量のデータを用いた．説明 変数は前節で述べた流域構成要因を重回帰分析で影響が あると判断された因子に加え，環境変動要因（年間降雨 量, 豪雨回数, 降雨時間数, 日平均気温）を用いた。断 続的なデータ（土地利用割合，製造品出荷額，家畜数） は線形補間を行い1981 2010年のデータを算定した.

重回帰分析の方法および精度評価は前節と同様の方法 で行い，各河川流域の流入水量, COD, T-N, T-P負荷 量の変動に及ぼす要因を分析した。 なお, 流域面積は経 年的な変化がないため, 説明変数から除外した.

\section{3. 結果と考察}

\section{（1）主要河川順流域の土地利用の変遷}

表-3に主要河川順流域の土地利用割合を示寸.
1976 2006年の期間において主要河川流域では市街地割 合が平均約3\%増加している程度であり，土地利用に大 きな変化はないものと考えられる。

有明海陸域（順流域十感潮域）における山林割合が 50\%程度であるのに対し，主要河川順流域の山林割合は 55\%程度であった。これは主要河川順流域が上流部に位 置しているため, 高い值を示していると考えられる。一 方, 嘉瀬川流域と矢部川流域では山林割合が70\%程度で あり, 白川流域と緑川支川加勢川流域の山林割合は30\% 程度となっており, 差が見られた. 有明海順流域では, 土地利用が流入負荷特性の違いを生む可能性があると考 えられる。

（2）有明海流入河川順流域における降雨パターンの変化

図-2に主要河川順流域の降雨パターン (年間降雨量, 豪雨回数，年間降雨時間数）の経年変化を示す. 降雨量, 年間降雨時間数の最大值は1993年で豪雨回数の最大值は

\section{表-2 流入水量・負荷量の流域環境変動解析に} 用いた変数とその入手元

\begin{tabular}{|c|c|c|c|}
\hline 使用変数 & 項目 & 単位 & データの入手元 \\
\hline \multirow{4}{*}{ 目的変数 } & 流入水量 & m3/year & \multirow{4}{*}{ 既往の研究 ${ }^{5)}$} \\
\hline & COD負荷量 & ton/year & \\
\hline & T-N負荷量 & ton/year & \\
\hline & T-P負荷量 & ton/year & \\
\hline \multirow{12}{*}{ 説明変数 } & 田割合 & $\%$ & \multirow{4}{*}{ 国土交通省 国土数値情報 } \\
\hline & 畑割合 & $\%$ & \\
\hline & 市街地割合 & $\%$ & \\
\hline & 山林割合 & $\%$ & \\
\hline & 流域人口 & 人 & 総務省 統計局 \\
\hline & 製造品出荷額 & 万円 & \multirow{3}{*}{ 有明流総 ${ }^{9)}$} \\
\hline & 牛 & 頭 & \\
\hline & 豚 & 頭 & \\
\hline & 年間降水量 & $\mathrm{mm}$ & \multirow{4}{*}{ 気象庁 } \\
\hline & 豪雨回数 & 回 & \\
\hline & 降雨時間数 & 時間 & \\
\hline & 日平均気温 & ${ }^{\circ} \mathrm{C}$ & \\
\hline
\end{tabular}

表-3 有明海流入主要河川順流域の土地利用割合

\begin{tabular}{|c|c|c|c|c|c|c|c|c|c|c|c|c|c|}
\hline \multicolumn{3}{|c|}{$\begin{array}{c}\text { 河川名 } \\
\text { (順流域面積) }\end{array}$} & $\begin{array}{c}\text { 本明川 } \\
\left(38.0 \mathrm{~km}^{2}\right)\end{array}$ & $\begin{array}{c}\text { 六角川 } \\
\left(32.3 \mathrm{~km}^{2}\right)\end{array}$ & $\begin{array}{c}\text { 牛津川 } \\
\left(94.0 \mathrm{~km}^{2}\right)\end{array}$ & $\begin{array}{c}\text { 嘉瀬川 } \\
\left(276.4 \mathrm{~km}^{2}\right)\end{array}$ & $\begin{array}{c}\text { 筑後川 } \\
\left(2316.7 \mathrm{~km}^{2}\right)\end{array}$ & $\begin{array}{c}\text { 矢部川 } \\
\left(450.9 \mathrm{~km}^{2}\right)\end{array}$ & $\begin{array}{c}\text { 菊池川 } \\
\left(897.7 \mathrm{~km}^{2}\right)\end{array}$ & $\begin{array}{c}\text { 白川 } \\
\left(480.0 \mathrm{~km}^{2}\right)\end{array}$ & $\begin{array}{c}\text { 加勢川 } \\
\left(191.5 \mathrm{~km}^{2}\right)\end{array}$ & $\begin{array}{c}\text { 緑川 } \\
\left(680.9 \mathrm{~km}^{2}\right)\end{array}$ & $\begin{array}{c}\text { 塩田川 } \\
\left(101.8 \mathrm{~km}^{2}\right)\end{array}$ \\
\hline \multirow{15}{*}{$\begin{array}{l} \pm \\
\text { 地 } \\
\text { 利 } \\
\text { 用 } \\
\text { 割 } \\
\text { 合 } \\
-\end{array}$} & \multirow{5}{*}{$\begin{array}{c}1 \\
9 \\
7 \\
6 \\
\text { 年 }\end{array}$} & 田 & 13.4 & 20.9 & 17.9 & 14.9 & 16.7 & 9.6 & 19.5 & 20.9 & 17.5 & 11.4 & 16.6 \\
\hline & & 畑 & 19.2 & 17.3 & 20.2 & 5.4 & 4.1 & 11.5 & 15.8 & 11.2 & 30.7 & 7.4 & 17.0 \\
\hline & & 市街地 & 6.2 & 4.8 & 6.4 & 2.4 & 5.0 & 2.6 & 4.9 & 5.9 & 8.1 & 1.6 & 4.7 \\
\hline & & 山林 & 58.2 & 56.3 & 53.0 & 72.9 & 63.0 & 74.7 & 52.2 & 30.6 & 30.9 & 62.8 & 59.4 \\
\hline & & その他 & 3.0 & 0.7 & 2.5 & 4.3 & 11.3 & 1.6 & 7.6 & 31.4 & 12.8 & 16.8 & 2.3 \\
\hline & \multirow{5}{*}{$\begin{array}{r}1 \\
9 \\
8 \\
7 \\
\text { 年 } \\
\end{array}$} & 田 & 13.2 & 20.8 & 17.0 & 14.8 & 15.3 & 9.2 & 19.1 & 21.0 & 20.0 & 11.6 & 15.6 \\
\hline & & 畑 & 14.9 & 15.6 & 18.0 & 5.1 & 5.2 & 12.9 & 15.0 & 10.1 & 24.7 & 7.5 & 16.2 \\
\hline & & 市街地 & 6.3 & 4.7 & 6.3 & 2.5 & 5.7 & 2.6 & 5.6 & 7.0 & 11.3 & 1.9 & 5.9 \\
\hline & & 山林 & 63.6 & 57.4 & 55.4 & 73.7 & 62.4 & 73.7 & 53.8 & 30.7 & 30.8 & 62.8 & 59.7 \\
\hline & & その他 & 2.0 & 1.5 & 3.3 & 3.8 & 11.3 & 1.5 & 6.5 & 31.2 & 13.2 & 16.2 & 2.5 \\
\hline & \multirow{5}{*}{$\begin{array}{l}1 \\
9 \\
9 \\
1 \\
\text { 年 }\end{array}$} & 田 & 13.2 & 20.6 & 16.6 & 14.8 & 15.3 & 9.2 & 19.0 & 20.9 & 19.7 & 11.6 & 15.6 \\
\hline & & 畑 & 14.9 & 15.3 & 17.9 & 4.9 & 5.4 & 12.9 & 15.0 & 10.0 & 24.4 & 7.7 & 16.2 \\
\hline & & 市街地 & 6.3 & 5.6 & 6.2 & 2.4 & 5.8 & 2.6 & 5.6 & 6.7 & 11.3 & 1.8 & 5.3 \\
\hline & & 山林 & 63.6 & 56.6 & 54.5 & 73.3 & 62.0 & 73.6 & 53.6 & 30.2 & 29.9 & 62.7 & 59.7 \\
\hline & & その他 & 2.0 & 1.8 & 4.8 & 4.5 & 11.5 & 1.7 & 6.8 & 32.2 & 14.8 & 16.2 & 3.2 \\
\hline \multirow[t]{10}{*}{$\%$} & \multirow{5}{*}{$\begin{array}{r}1 \\
9 \\
9 \\
7 \\
\text { 年 } \\
\end{array}$} & 田 & 13.2 & 19.8 & 15.8 & 14.9 & 14.8 & 9.0 & 18.8 & 22.4 & 19.2 & 12.0 & 15.5 \\
\hline & & 畑 & 15.5 & 15.2 & 18.1 & 5.0 & 6.2 & 13.5 & 15.4 & 7.9 & 23.6 & 8.3 & 16.1 \\
\hline & & 市街地 & 7.2 & 8.7 & 8.2 & 3.2 & 8.7 & 3.3 & 7.5 & 9.3 & 13.6 & 4.7 & 7.6 \\
\hline & & 山林 & 62.3 & 54.2 & 52.7 & 72.7 & 60.8 & 72.5 & 51.8 & 29.2 & 28.8 & 61.0 & 57.7 \\
\hline & & その他 & 1.9 & 2.1 & 5.2 & 4.2 & 9.5 & 1.8 & 6.4 & 31.3 & 14.8 & 14.0 & 3.1 \\
\hline & \multirow{5}{*}{$\begin{array}{c}2 \\
0 \\
0 \\
6 \\
\text { 年 } \\
\end{array}$} & 田 & 12.0 & 17.5 & 15.1 & 14.0 & 13.5 & 8.1 & 18.1 & 22.5 & 22.8 & 11.0 & 14.4 \\
\hline & & 畑 & 16.3 & 13.0 & 15.2 & 3.8 & 5.3 & 13.0 & 14.8 & 7.5 & 19.3 & 7.5 & 13.7 \\
\hline & & 市街地 & 8.8 & 9.0 & 9.0 & 3.6 & 10.8 & 3.2 & 8.9 & 9.5 & 13.0 & 4.8 & 7.3 \\
\hline & & 山林 & 60.8 & 57.5 & 53.7 & 73.9 & 61.3 & 71.4 & 51.3 & 30.0 & 30.3 & 62.5 & 60.8 \\
\hline & & その他 & 2.0 & 3.0 & 7.0 & 4.7 & 9.2 & 4.3 & 7.0 & 30.5 & 14.6 & 14.2 & 3.9 \\
\hline
\end{tabular}


1997年であり，年間降雨量，豪雨回数，年間降雨時間数 の最小值は1994年となっていた。降雨パターンの変化は, 全主要河川順流域でほぼ同様の傾向であった。

降雨パターンの1981 1995，1996 2010年の2期間でF 検定とt検定を行った結果，年間降雨量，豪雨回数，年 間降雨時間数の全項目で有意差がなく $(\mathrm{p}>0.05)$, 経年的 な降雨パターンの変化はないと考えられた，そこで，平 水時 (降雨の影響を受けない) と出水時（降雨の影響を 受ける）に分けて，河川ごとの流入負荷特性について考 察を行う.

\section{（3）各河川における平水時と出水時の流入特性}

図-3に1981 2010年の各河川順流域における比流量, 比負荷量(COD，T-N，T-P)の平均值を平水時分と出水時 増分に分けて示す.

平水時分の比負荷量, COD, T-N, T-P負荷量では加 勢川流域が高い值を示した. 出水時増分の比流量, 比TN負荷量では塩田川流域が最も高い值を示し，比COD， T-P負荷量では白川流域が最大值であった.

比流量については，平水時分＜出水時増分となってい るものは本明川，六角川，牛津川，矢部川，塩田川流域 であり, 平水時分>出水時増分となっているものは嘉瀬 川, 筑後川, 㐘池川, 白川, 緑川で流域あった。これら は土地利用の空間分布や表層地質の分布などの影響によ るものと考えられる.

比COD，T-P負荷量では，加勢川流域以外の全ての流 域で平水時分＜出水時増分という関係になっていた．有 機物とリンについては出水時に懸濁態の有機物やリンが 増加するという報告がある ${ }^{10)}$.

比T-N負荷量では，ほとんどの河川が比流量の平水時 分と出水時増分の大小関係と同じになっているが，菊池 川, 緑川流域の平水時分と出水時増分の大小関係が比流 量と比べ逆転し, 出水時増分の值が高くなっていること が分かる. 比T-N負荷量については，降雨時（出水時） の河川で土壤からの溶脱による硝酸態窒素 $\left(\mathrm{NO}_{3}-\mathrm{N}\right)$ 濃度 の増加が報告されており ${ }^{11)}$, 降雨時流出のファーストフ

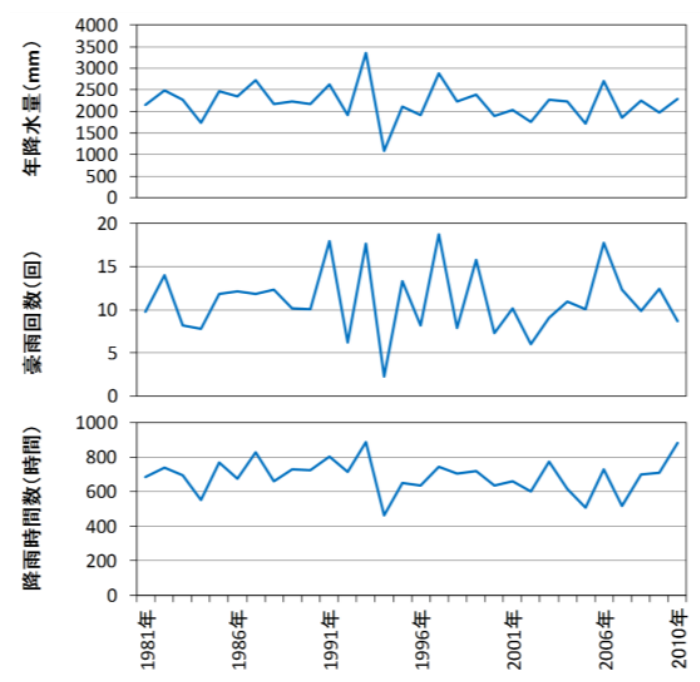

図-2＼cjkstart有明海の降雨パターンの経年変化
ラッシュの影響によりアンモニウム態窒素 $\left(\mathrm{NH}_{4}{ }^{+}-\mathrm{N}\right)$ 濃度 が増加すると考えられる ${ }^{12)}$. このように出水時では流域 要因や環境变動要因が流入特性に影響を与えると考えら れる.

加勢川流域には豊富な地下水が存在し，江津湖など多 数の湧水群が存在している ${ }^{13)}$. 特に江津湖は年平均湧水 量が約40万 $\mathrm{m}^{3} \cdot$ day $^{-1}$ であり，加勢川流域からの流出量 の約4割を占めているといわれている. 加勢川流域とそ の他の主要河川流域の順流域末端地点の水質観測所での 平均水質を比べると, COD濃度は $3.1 \mathrm{mg} / \mathrm{L}$ で約 1.2 倍, $\mathrm{T}$ N濃度は3.65mg/Lで約 2 倍, T-P濃度は $0.223 \mathrm{mg} / \mathrm{L}$ で約 1.8 倍であった。

白川流域では比COD負荷量が他流域と比べ1.5倍程度 高い值を示した。白川流域には，「ヨナ」と呼ばれる黒 ボク土が多く分布している ${ }^{14)}$.「ヨナ」には有機物含有 量が多く, 比重が軽いため土壌が降雨などにより流出し やすいという特徴がある ${ }^{15)}$. 白川の時間雨量・負荷量 データを確認した結果，豪雨時においてCOD負荷量が
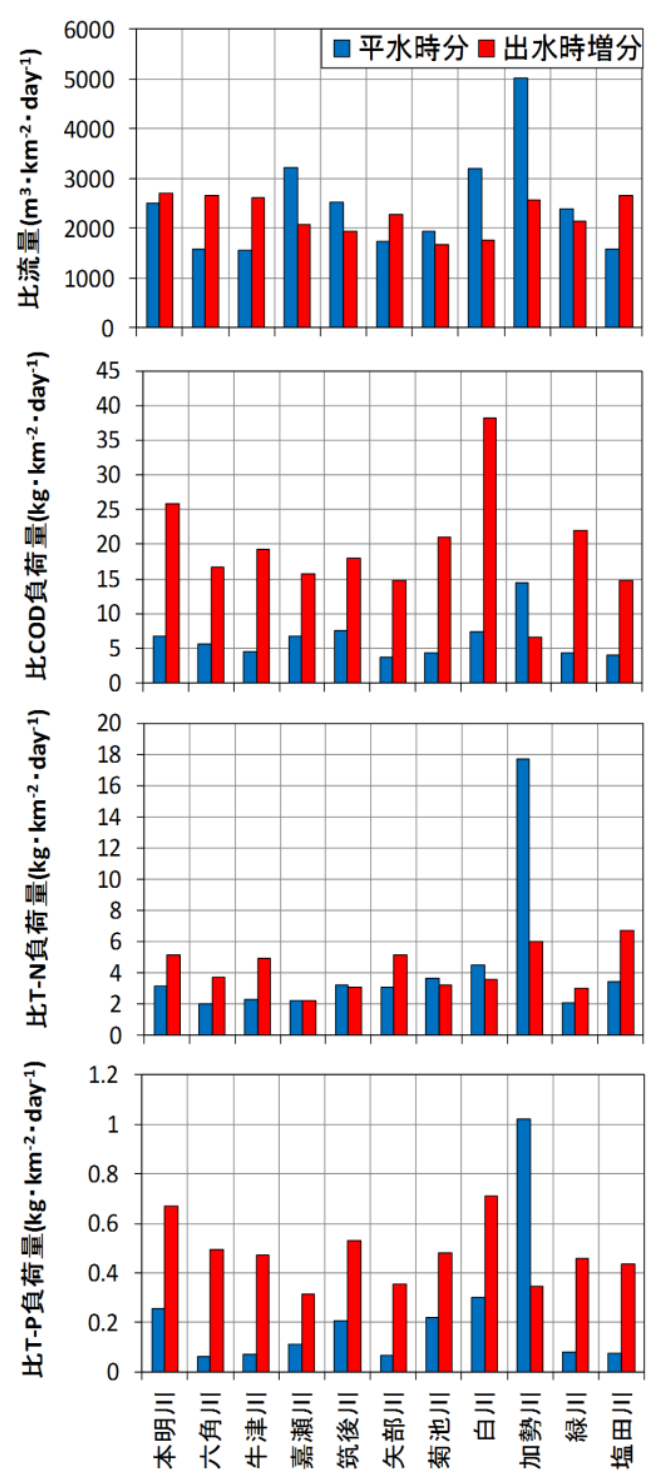

図-3 平水時分および出水時増分の 比流量と各負荷量の流入特性 
増加している傾向がみられた，そのため，白川流域では 降雨により「ヨナ」が巻き上げられ，流域の末端に流出 したことによってCOD負荷量が増加する特徴があると 考えられる.

前述した因子以外にも流入水量・負荷量を特徵づける 要因が考えられるが，単純なデータの比較のみでは流入 水量・負荷量の影響因子を十分に抽出することが難しい と考えられる。そこで，各河川流域の流入水量・各負荷 量と流域構成要因・環境変動要因データを用いて重回帰 分析を行い，流入水量・負荷量に影響を及ぼす因子につ いて考察を進める.

\section{（4）流入水量·負荷量に影響を及ぼす流域構成要因の抽 出}

重回帰分析により抽出した流入水量, 各負荷量に及ぼ す流域構成要因を表-4に示寸. 流入水量と各負荷量の全 てで流域面積の標準偏回帰係数が高く, 影響を大きく受 けることが分かった．これは，流入水量と各負荷量が降 雨に依存するためであると考えられる，また，流入水量 と各負荷量全てで補正済み视が0.95を超える值となり， 表-4に示寸説明変数で各負荷量を十分に説明できた.

また，COD負荷量では山林と畑，T-N負荷量では市街 地，T-P負荷量では畑と市街地が影響因子として抽出さ れた. 土地利用割合の違いによる負荷量の影響を把握す るため, 仮に説明変数の山林割合を $1 ， 3 ， 5 \%$ 増加させ た場合，COD負荷量は8，40，65\%程度減少する。烟割 合を $1 ， 3 ， 5 \%$ 増加させた場合，COD負荷量は5，5, 27\%程度減少し，T-P負荷量は3，9，13\%程度減少する。 市街地割合を1，3，5\%増加させた場合，COD負荷量で は変化が見られず，T-N負荷量では2，5，8\%増加し，TP負荷量では5，14，24\%程度増加した。 以上の結果から， 土地利用割合の変化が各負荷量に与える影響が示唆され た。このように主要河川順流域全てで考えると, 流入水 量・負荷量に影響を及ぼす流域構成要因として, 流域面 積と土地利用割合が抽出された。しかし，各河川を個別 に考えると, 流域面積の変化はなく, 土地利用割合の変 化は小さいため, 影響因子とはならない，一方，平水時 と出水時の流入特性の相違から, 降雨などの環境変動要 因が流入水量・負荷量に影響を及ぼすと考えられた。 そ こで各河川における流入水量・各負荷量の影響因子につ いて, 抽出した流域構成要因と環境変動要因を用いた重 回帰分析により検討した.

\section{（5）各河川における流入水量 ·負荷量の影響因子}

重回帰分析により抽出した環境変動要因が流入水量と 負荷量に及ぼす影響度を表-5に示寸. 標準偏回帰係数が 高いことから全河川流域の流入水量, COD, T-N, T-P 負荷量の全項目で年間降雨量が影響する因子ということ が分かった.

本明川，六角川，筑後川，菊池川，緑川，矢部川，白
表-4 重回帰分析による流入負荷の流域構成要因

\begin{tabular}{|c|c|c|}
\hline \multicolumn{3}{|c|}{ 流入水量 } \\
\hline \multicolumn{3}{|c|}{ 標準偏回帰係数 有意水準 } \\
\hline 流域面積 & 0.974 & $p<0.01$ \\
\hline 決定係数 $\mathrm{R}^{2}$ & 0.987 & \\
\hline 自由度調整済み決定係数 & 0.986 & \\
\hline \multicolumn{3}{|c|}{ COD負荷量 } \\
\hline & 標準偏回帰係数 & 有意水準 \\
\hline 流域面積 & 0.916 & $p<0.01$ \\
\hline 山林割合 & -0.946 & $p<0.01$ \\
\hline 畑割合 & -0.487 & $p<0.01$ \\
\hline 決定係数 $\mathrm{R}^{2}$ & 0.994 & \\
\hline 自由度調整済み決定係数 & 0.992 & \\
\hline \multicolumn{3}{|c|}{ T-N負荷量 } \\
\hline & 標準偏回㷌係数 & 有意水準 \\
\hline 流域面積 & 0.850 & $p<0.01$ \\
\hline 市街地割合 & 0.551 & $p<0.05$ \\
\hline 決定係数 $\mathrm{R}^{2}$ & 0.969 & \\
\hline 自由度調整済み決定係数 & 0.961 & \\
\hline \multicolumn{3}{|c|}{ T-P負荷量 } \\
\hline & 標準偏回帰係数 & 有意水準 \\
\hline 流域面積 & 0.969 & $p<0.01$ \\
\hline 市街地割合 & 0.814 & $\mathrm{p}<0.01$ \\
\hline 畑割合 & -0.373 & $p<0.01$ \\
\hline 決定係数 $\mathrm{R}^{2}$ & 0.998 & \\
\hline 自由度調整済み決定係数 & 0.997 & \\
\hline
\end{tabular}

川の流入水量の補正済み $\mathrm{R}^{2}$ は 0.8 以上であり, 流入水量 は年間降雨量のみで十分説明が可能であると考えられた。 その他の河川で低い值を示した原因は, 本研究で考慮し ていない, 地下水位の変化やダムの放流量等の影響が考 えられる.

COD，T-P負荷量では，塩田川以外の全河川で豪雨回 数が影響因子として抽出された. よって, 白川流域の

「ヨナ」の流出のように, 他流域においても土壤流出が 負荷量変動に影響を及ぼしている可能性が示唆される.

流入水量と比較すると各負荷量の補正済み视が低い. その原因として, 本研究では考慮していない地下水位, ダムの放流や下水放流量の変化等が影響している可能性 がある.

牛津川のCOD, T-N負荷量では流域人口が影響し，矢 部川流域の流入水量, T-P負荷量では畑割合, COD, TP負荷量では日平均気温が影響した。白川のCOD, T-P 負荷量では製造品出荷額が影響し, 加勢川の流入水量, COD負荷量では畑割合，家畜数（牛）, T-N, T-P負荷 量では市街地割合, 製造品出荷額, 家畜数 (牛) が影響 因子として抽出された。 このように各河川流域からの流 入水量, 各負荷量に影響を及ぼす因子を抽出し, 有明海 順流域の特性の一端を明らかにすることができた。

\section{4. 結論}

本研究で得られた結論を以下に示す.

（1）1976～2006年の期間で有明海流入主要河川順流域の 土地利用は大きな変化がなかった。 また, 有明海陸 域の降雨パターンに経年的な変化がないと考えられ た. 
表-5 重回帰分析による各河川での流入水量 - 負荷量の影響因子

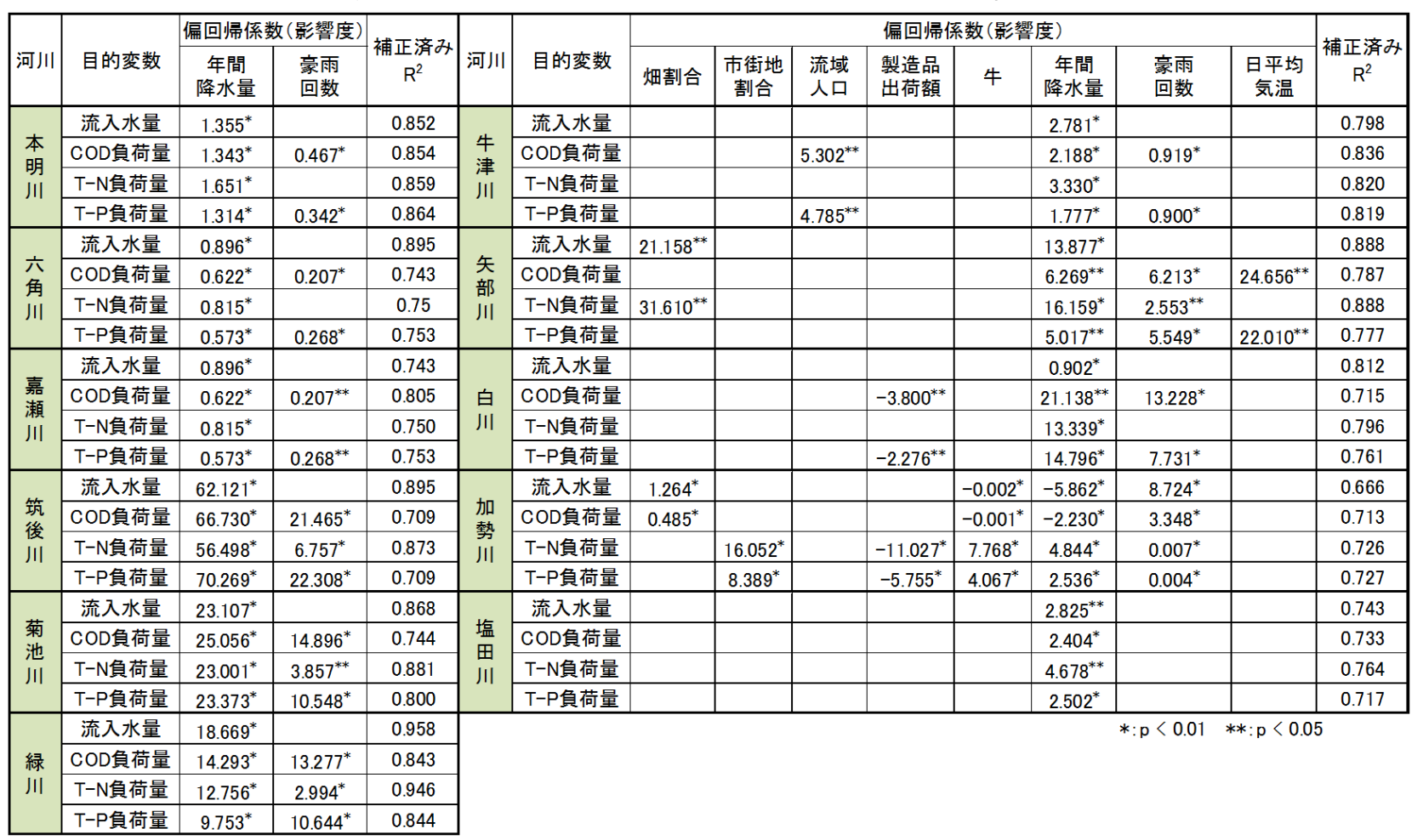

（2）有明海流入主要河川の平水時分と出水時増分の比流 量, 各比負荷量を比較することで，河川により出水 時の負荷量の増加特性が異なることが分かった．ま た，緑川支川加勢川流域の流入水量, COD, T-N, T-P負荷量は湧水の影響，白川流域のCOD負荷量は 有機物含有量が多く比重の軽い黒ボク土の影響を受 けているものと考えられた.

（3）流域構成要因を用いた重回帰分析による流入水量・ 負荷量の影響因子解析により，有明海流入主要河川 順流域の流入水量, COD, T-N, T-P負荷量全てで 流域面積が影響因子として抽出された。また，土地 利用の変化が流入負荷量に与える影響が示唆された

（4）環境変動要因を用いた重回帰分析による流入水量 負荷量の影響因子解析から，有明海流入11河川の流 入水量と各負荷量の変動に及ぼす因子を河川毎に抽 出し, 年間降雨量が流入水量・負荷量の変動に与え る影響が大きいことが分かった。

謝辞 : 本研究は, 平成24年度笹川科学研究助成および科 研費基盤研究（A）（21246078，代表者：松永信博）の 助成を受けたものである.データを頂いた国土交通省, 農林水産省，環境省，気象庁，デー夕整理にご協力頂い た佐賀大学流域水工学研究室の皆様に謝意を表します.

\section{参考文献}

1) 堤 裕昭ほか:陸域からの栄養塩負荷量の増加に起因しない有 明海奥部における大規模赤潮の発生メカニズム, 海の研究, Vol.15(2), pp.165-189, 2005.

2) 小松 利光ほか:有明海の潮流ならびに物質輸送の変化に関す
万研究, 海岸工学論文集, Vol.53, pp.326-330, 2006.

3) 環境省有明海・八代海総合調査評価委員会: 委員会報告, 2006 4) 朴童津ほか: 有明海の全流域における環境変化が流出量に与 える影響の評価, 水工学論文集, Vol.53, pp.481-486, 2009.

5) 手塚公裕ほか:有明海における陸域負荷の長期変動の推定お よび赤潮発生に及ぼす流入水量の影響, 水工学論文集,

Vol.57, pp.1735-1740, 2013.

6) 二瓶泰雄ほか: 江戸川・荒川・多摩川における水質環境と流入 負荷特性, 京都大学防災研究所年報, Vol.46, pp.233-248, 2003.

7) 立川康人ほか:分布型流出モデルにおける空間分布入力情報 の有效性の評価, 京都大学防災研究所年報, Vol.46, pp.233248, 2003.

8) 財団法人日本ダム協会:ダム年鑑, 2011.

9) 九州地方整備局:有明海水域に係る下水道整備総合計画に関 する基本方針策定調査報告書, 2005 .

10) 手塚公裕ほか:増水時における流入栄養塩負荷が閉鎖性水域 の藻類増殖に与える影響, 土木学会論文集, No.804,VII-37, pp.101-111, 2005.11.

11) 海老瀬潜一: 降雨による土壌層からの河川への NO3-の排出, 衛生工学研究論文, Vol.21, pp.57-68, 1985.

12) 海老瀬潜一:面源負荷の流出に及ぼす水文条件の影響, 国立 公害研究所研究報告, No.95, pp.57-70, 1986.

13) 九州地方整備局: 緑川水系河川整備計画【原案】,2011. 14) 九州地方整備局 : 白川河川改修事業, 2009.

15) 矢野締之ほか：雲仙の火山性土に関する研究（第 3 報） 雲仙岳東北部の火山灰土壌の理化学的性質, 佐賀大學 農學彙報, Vol.40, p.55 -66, 1976.

(2013. 9. 30受付) 